\title{
On a New Pteridosperm possessing the Sphenopteris Type of Foliage.
}

\author{
BY \\ E. A. NEWELL ARBER, M.A., F.L.S., F.G.S. \\ Trinity College, Cambridge ; University Demonstrator in Palaeobotany. \\ With Plate VI.
}

$7 \mathrm{HE}$ discovery of the seed of Lyginodendron on the part of Professor 1 Oliver and Dr. Scott, ${ }^{1}$ followed more recently by that of the male fructification (Crossotheca) by Mr. Kidston ${ }^{2}$, has rendered our knowledge of this fossil scarcely less complete than it would have been had the genus still survived at the present day. One or two points, however, remain to be determined. Of these perhaps the most important relates to the manner in which the seeds were borne. It will be remembered that, when the seed Lagenostoma Lomaxi was first attributed to Lyginodendron, no direct evidence of continuity could be demonstrated. But in the case of other Lagenostomas, subsequently described, ${ }^{3}$ there did appear to be strong evidence in favour of the view that the seeds, like the male organs, were borne on fronds with reduced lamina. ${ }^{4}$ The present specimen, though not obviously a member of the same genus, tends to confirm this conclusion in a somewhat emphatic manner.

The fossil frond figured here belongs to the series of Coal Measure fossils which constitute the Goldenberg collection, preserved in the Museum of Fossil Botany of the Swedish Academy of Sciences at Stockholm. I am indebted to my friend Prof. A. G. Nathorst, Keeper of the Museum, for facilities for examining this and other collections under his care, and I would here express my very sincere thanks to him for generously giving me permission to describe this specimen, and for permitting me to borrow it for that purpose.

Goldenberg's collection, part of which was illustrated in his 'Flora Saraepontana Fossilis,' published between I 855 and I 862 , of which, however, only a portion ever appeared, was derived from the Saar-Rhein

${ }^{1}$ Oliver and Scott ('04). $\quad{ }^{3}$ Kidston ('06). $\quad{ }^{3}$ Arber $\left({ }^{\prime} 05^{1}\right) . \quad 4$ Arber $\left(05^{2}\right)$.

[Annals of Botany, Vo1. XXII. No. LXXXV. January, 1908.] 
Coalfield of Germany. The present specimen, collected many years ago, was not among those described by Goldenberg. The locality from which it was derived is given on the label as 'Judenschlag Graben'. The horizon is probably that of the Westphalian division of the Upper Carboniferous, using the term in the sense in which it is applied on the Continent. The fossil is labelled, probably by Goldenberg, as a new species of Hymenophyllum, and, in another handwriting, as a fertile Sphenopteris.

The specimen consists of a piece of shale, of uneven surface, about $20 \mathrm{~cm}$. in length, showing on one side part of a fertile Sphenopterid frond with several seeds still in continuity. The more interesting portion of this frond is figured on Pl. VI, Fig. I, magnified three times. On the reverse side, a leaf of an Alethopteris, no doubt A. lonchitica (Schl.), is seen. The anatomical structure is not preserved, the fossil being simply an impression. Although fragmentary in places owing to the uneven bedding of the shale, the preservation of the frond as a whole is quite satisfaciory.

The portion of the leaf figured (Pl. VI, Fig. I) is no doubt only: a small part of a highly compound frond, just as is the case with the majority of impressions of the Sphenopteris type. A fragment of the rachis of the second, or some higher order, is seen on the right of the figure. Most of the pinnae are obviously detached, but in two cases, one of which is shown in the drawing, they appear to be still in continuity with the axis.

The frond as a whole appears to have been of a delicate, graceful type, the leaflets, like those of several other species of the same genus, being quite small and very narrow.

The rachis has a breadth of about $3 \mathrm{~mm}$. The surface is faintly striated longitudinally, but shows no signs of the presence of any glandular organs, similar to those which often occur so abundantly on the rachis of Sphenopteris (Lyginodendron) Hoeninghausi, Brong. Another rachis of greater breadth is also associated, but it is by no means obvious that it had any real connexion with the frond under discussion.

The pinnae of the highest order, of which three are seen on Pl. VI, Fig. I, were slender axes, which probably, in the living state, exceeded $5 \mathrm{~cm}$. in length. None of the fragments of pinnae shown on this specimen are however complete. The pinnules were numerous, subopposite, and reached a length of $1 \mathrm{~cm}$. or more. They were deeply divided into a number of very narrow, linear segments, of about $1.5 \mathrm{~mm}$. in length, the lamina as a whole being very small, and probably considerably reduced in comparison with the, as yet unknown, sterile frond (Plate VI, Figs. I, 3, 4, 5, 7, and 8).

The great majority of the pinnules seen in this specimen appear to have been fertile, the seeds being borne at the extremities of the linear segments or lobes (Plate VI, Figs. 4, 5, 7, and 8). The absence of seeds, in certain cases, is probably due to some accident during preservation. 
Usually each of the segments bears a single seed, though more rarely they appear to have bifurcated, each lobe terminating in a seed.

\section{The SeEds.}

The seeds themselves are extraordinarily small objects. Two examples are figured on Plate VI, Figs. 2 and 3 , magnified twenty times. Their average length is about a millimetre, the largest being $1 \cdot 2 \mathrm{~mm}$., while at their greatest width they measure $.75 \mathrm{~mm}$. across. They seem to be of the radially symmetrical type. They are more or less oval in shape, and exhibit several rather sharp, longitudinal ridges (Pl. VI, Fig. 3). They do not appear to show any special apical peculiarities.

There would seem to be some grounds for the belief that most of the seeds seen on this specimen are enveloped in closely-fitting cupules (Plate VI, Figs. 4-8). It is, however, very difficult to decide whether such an organ is really present, for not only are the seeds very minute, but the cupules, if they exist, are closely similar to them in size and shape. In such impressions as these, it must always be difficult to demonstrate the presence of a cupule, unless it has, as in the case of Lagenostoma Sinclairi, Kidst. MS. ${ }^{1}$, a form quite different from that of the seed itself, or unless it is a deeply cleft structure, as for instance in Calymmatotheca Stangeri, Stur ${ }^{2}$. In the present case, if cupules are present, they appear to correspond more closely to those of Lagenostoma Lomaxi ${ }^{3}$, though they are perhaps less deeply divided, and without the glandular structures found on the cupule of that seed. Impressions of such cupules must naturally be difficult to distinguish from those of the seeds themselves.

In this specimen, there do not appear to be any good cases in which empty cupules, without seeds, can be recognized. On Pl. VI, Fig. 2, there is a somewhat indefinite body, seen to the right of the naked seed, which may be of this nature, but it is impossible to determine its precise nature.

In many instances, however (Pl. VI, Figs. $5^{-8}$ ), there are indications which suggest the presence of an outer investment containing a seed, the surface of which does not appear to correspond exactly with that of the naked seed. In such cases, the shape of the supposed cupule differs somewhat from that of the seed itself, and its length and breadth are slightly greater. The longitudinal ridges are also less prominent. Here and there, examples (Pl. VI, Figs. 5 and 6) may be found, which appear to show that the outer investment or cupule may have been lobed, though at this stage of development the lobes remained appressed to the seed, and were not

\footnotetext{
1 Arber $\left({ }^{\prime} 05^{1}\right)$.

2 Stur ('77), p. I5I, Pl. VIII (XXV), Figs. $5-7$, and Text-fig. 27 on p. I 58 .

O Oliver and Scott ('04), p. 217 , Text-fig. 2.
} 
reflexed. On the whole, so far as one may arrive at a provisional conclusion, it seems probable that these seeds were enclosed in cupules, not unlike those of Lagenostoma Lomaxi in some respects, but perhaps having a closer resemblance to certain other fossils, which may now be reviewed in this connexion.

Since the discovery of the seed of Lyginodendron it has been generally agreed that certain organs borne on Palaeozoic fern-like fronds, such as Calymmatotheca Stangeri, Stur ${ }^{1}$, and possibly Zeilleria delicatula (Sternb.) ${ }^{2}$, whose nature had hitherto remained obscure, are in all probability persistent cupules from which the seeds have fallen. The fertile fronds of the latter species are very closely similar to that described here. The cupules are even smaller, and, at the same time, appear to have been more deeply cleft than in the present instance. But this latter feature no doubt depends to some extent on the state of maturity of the frond at the time when fossilization took place.

Again in Calymmatotheca Frenzli, Stur ${ }^{3}$, we have in all probability a fertile frond with cupules still in continuity, agreeing fairly closely in habit with the present specimen, and with cupules of about the same size, cleft at the apex into several lobes, as is apparently the case here.

The remarkably small size of the seeds may raise the question whether these organs are really of that nature. The smallest Lagenostoma (L.ovoides, Will.) known in the petrified state has a length of $4.5 \mathrm{~mm}$. In the case of $L$. Sinclairi, Kidst. MS., a species founded on an impression, the length is $4-5.5 \mathrm{~mm} .^{4}$ Most of the other seeds, suspected of being of Pteridospermous affinity, are much larger. On the other hand the seed, Gnetopsis elliptica, Ren. and Zeill., has a length of $2 \mathrm{~mm}$. There does not appear to me to be any valid objection to the present conclusion, merely on the score of size, for a large number of species of the frond genus Sphenopteris are known in which the segments of the pinnules are, as in the present instance, very small indeed, and one would naturally expect to find, in such cases as may prove to belong to the Pteridosperms, some correspondence between the size of the seeds and the pinnules which bore them. Again these fructifications have all the characters of a seed on a small scale (cf. Pl. VI, Figs. 2 and 3), and do not in the least resemble any known Palaeozoic sporangia or synangia. Further, the possibility, by no means slight, that the seeds are invested in cupules, strengthens this conclusion.

${ }^{1}$ Stur, ibid., see also Oliver ('05), p. 4I 2, Text-fig. 6.

${ }^{2}$ Kidston ('84), p. 590, Pl. XXV. It seems to me conceivable that the specimen figured by Kidston, Pl. XXV, Fig. 2, and described (p. 598) as showing ' closed globular involucres,' representing 'the fruit in an early state of development' may, judging by the figure, be a case in which the seeds are still enclosed in their cupules. The general similarity of the specimen to that figured here is striking.

${ }^{3}$ Stur ('85), p. 268 , Pl. XXXVIII, Fig. 3, Pl. XXXVII, Figs. $2-3$, and Text-fig. 42 on p. 239.

* Arber $\left({ }^{\prime} 05^{1}\right)$, p. $25^{2}$. 
The next point to be considered is the identity of the seed. In some respects this organ agrees closely with Lagenostoma ovoides, Will., but it is on a very much smaller scale. I have not however been able, owing to the minute size of the specimens, to ascertain the characters of the apex in the few instances in which the seed appears to be free from the cupule. Further, it must always be difficult to correlate a seed, occurring as an impression, with one in which the structure is preserved. I do not therefore feel justified, on the present evidence, in referring it to the genus Lagenostoma, though I think it probable that it may eventually prove to be nearly related. As it seems advisable to adopt some name for the present specimen, I propose to include the seeds temporarily in the non-committal genus Carpolithus, a term already applied to certain seeds of this type, whose affinities are uncertain. As regards the specific name, I would designate it $C$. Nathorsti, sp. nova, in honour of my friend Prof. Nathorst, of Stockholm, who has done so much to increase our knowledge of fossil plants.

The Sphenopterid frond described here does not agree exactly with any species with which I am acquainted. It is however similar to the fertile fronds of Zeilleria delicatula (Sternb.), and Calymmatotheca Frenzli, Stur. I doubt whether it could be determined specifically, in the present instance, for the lamina appears to be much reduced. I do not therefore propose to designate it other than generically.

\section{CONCLUSIONS.}

The interest of the present specimen lies in the fact that we have here the very rare instance of a female frond, undoubtedly of the Sphenopterid type, bearing small seeds, probably enclosed in cupules. The inferences are all in favour of the inclusion of this fossil within the Lyginodendreae, although it is impossible, at present, to ascertain whether the seed in question was a true Lagenostoma, or a member of some other nearly-related genus. The small size of the seeds themselves, though remarkable, is not inexplicable when we remember that the pinnules of many of the Sphenopterid fronds, which at present rest under the suspicion of being the foliage of Pteridosperms, rather than members of the Primofilices ${ }^{1}$, have often quite minute segments or lobes.

Further, in Carpolithus Nathorsti we have the first instance where seeds, probably enclosed in cupules, have been found attached to a Sphenopterid frond, the lamina of which can be recognized. Thus perhaps the greatest point of interest of this specimen lies in the fact that the provisional conclusions ${ }^{2}$, previously drawn from the evidence of Lagenostoma

1 Arber ('06), p. 2 I 8.

2 Oliver and Scott ('04), p. 229 . Arber ('05 1 , P. $25^{8}$; Arber ('052). 
Lomaxi, Will., L. Kidstoni, Arber, and L. Sinclairi, Kidst. MS., as to the habit of the fertile fronds, receives strong confirmation if from an indirect source. That the Lyginodendreae, in common with all the other known members of the class Pteridospermeae, were characterized by an absence of any aggregation of either the male or female organs into cones or stroboli, is a fact of great importance, in view of the strobilate descendants which were probably derived from them in Mesozoic times.

\section{BIBLIOGRAPHY.}

Arber, E. A. N. ('05'1): On some New Species of Lagenostoma, a type of Pteridospermous Seed from the Coal Measures. Proc. Roy. Soc. London, vol. B. 76, p. 245, I905.

$\left({ }^{\prime} 05^{2}\right)$ : The seed-bearing habit in the Lyginodendreae. Proc. Cambr. Phil. Soc., vol. xiii, pt. iii, p. 158,1905 .

('06): On the Past History of the Ferns. Ann. of Bot., vol. xx, p. $215,1906$.

Kidston, R. ('84): On the Fructification of Zeilleria (Sphenopteris) delicatula, Sternb. sp., \&c. Quart. Journ. Geol. Soc., vol. xl, p. 590, I 884.

('06): On the Microsporangia of the Pteridospermeae, with remarks on their relationship to Existing Groups. Phil. Trans. Roy. Soc., Ser. B, vol. 198, p. 4I 3, I906.

Oliver, F. W. ('05): Über die neuentdeckten Samen der Steinkohlenfarne. Biolog. Centralbl., vol. $x x v$, p. 4 OI, 1905 .

Oliver, F. W. and ScotT, D. H. ('04): On the Structure of the Palaeozoic Seed Lagenostoma Lomaxi, with a statement of the evidence upon which it is referred to Lyginodendron. Phil. Trans. Roy. Soc., vol. 197 B, p. 193, I904.

Stur, D. ('77) : Die Culm-Flora. II. Die Culm-Flora der Ostrauer und Waldenburger Schichten. Abhandl. K. K. Geol. Reichsanst. Wien, vol. viii, pt. ii, 1877.

('88): Die Carbon-Flora der Schatzlarer Schichten. Abth. I.: Die Farne. Abhandl. K. K. Geol. Reichsanst. Wien, vol. xi, I885.

\section{EXPLANATION OF PLATE VI.}

Iilustrating Mr. Arber's paper on Carpolithus Nathorsti, sp. nova.

(Drawings by Miss G. M. Woodward.)

Fig. I. Impression of 3 pinnae of a Sphenopteris frond, bearing a large number of seeds, many still in continuity. $\times 3$.

Fig. 2. Detached seed. $\times 20$.

Fig. 3. Seed attached to a lobe which has become broken away from the rest of the pinnule. $\times 20$.

Fig. 4. Pinnule showing several seeds in continuity, probably still enclosed in their cupules. $\times 7$. $\times 7$.

Fig. 5. Seeds apparently enclosed in cupules, and in continuity with lobes of the pinnules.

Fig. 6. Seeds apparently enclosed in cupules. $\times$ ro. $\times 10$.

Fig. 7. Two seeds, probably still enclosed in their cupules, borne on the lobes of a pinnule. $\times 8$.

Fig. 8. Seeds apparently enclosed in cupules and borne at the ends of the linear lobes of pinnules. 

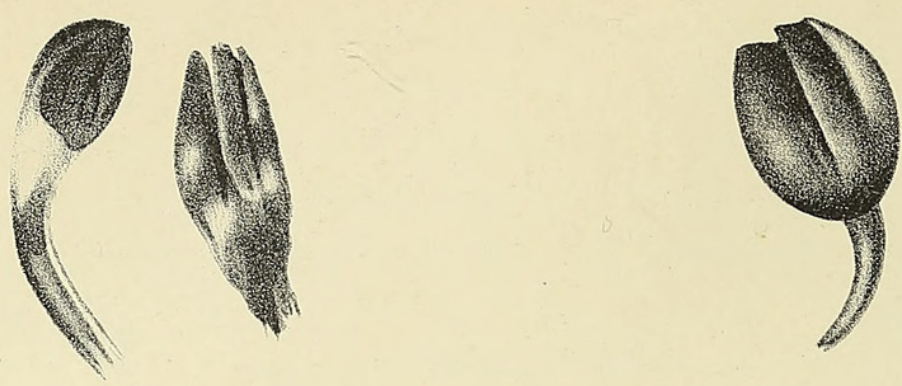

6.
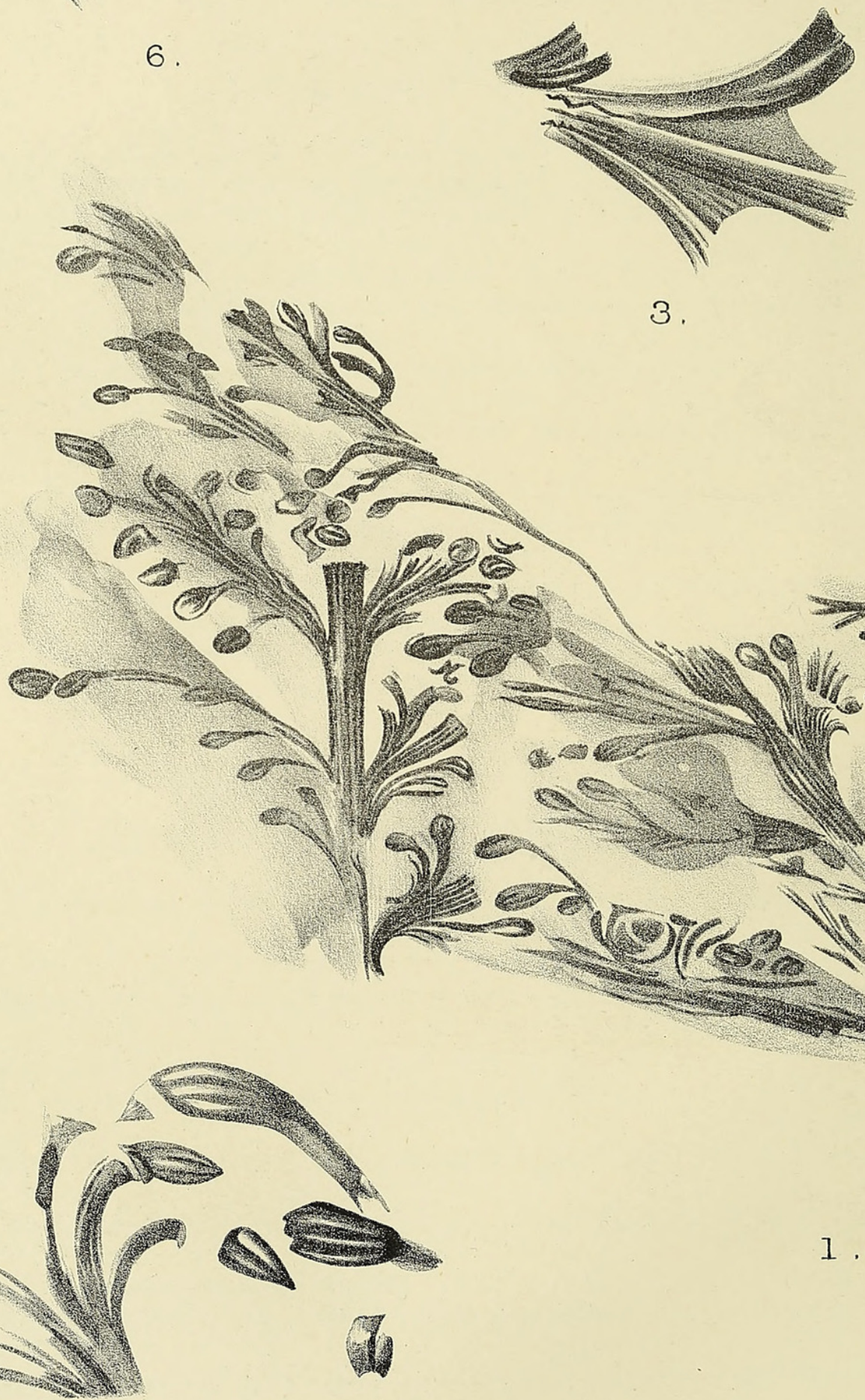

3.

8.

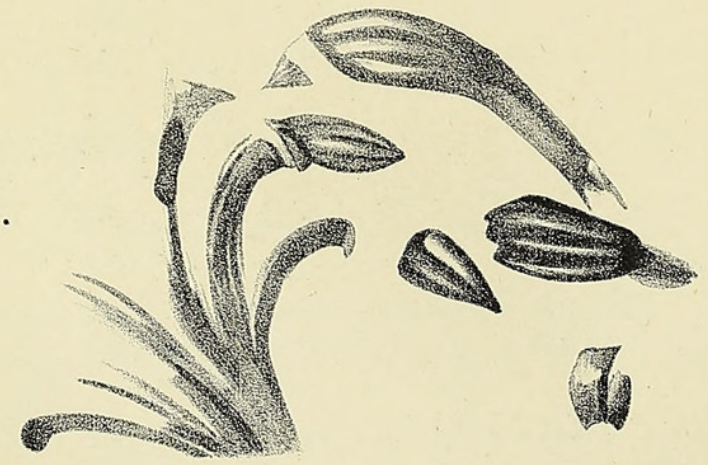




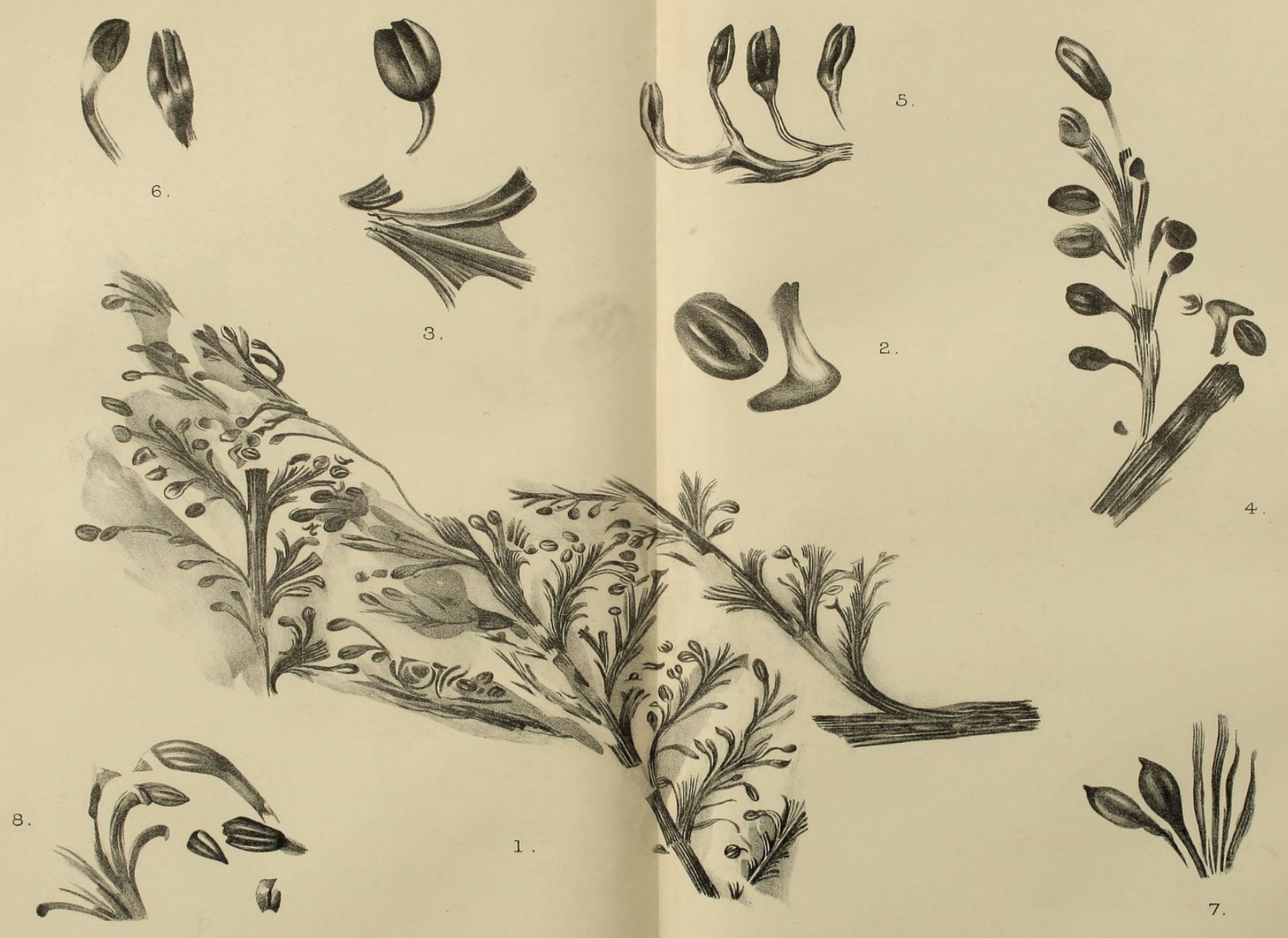




\section{$2 \mathrm{BHL}$ Biodiversity Heritage Library}

Arber, E. A. Newell. 1908. "On a new Pteridosperm possessing the sphenopteris type of foliage." Annals of botany 22, 57-62.

https://doi.org/10.1093/oxfordjournals.aob.a089162.

View This Item Online: https://www.biodiversitylibrary.org/item/232525

DOI: https://doi.org/10.1093/oxfordjournals.aob.a089162

Permalink: https://www.biodiversitylibrary.org/partpdf/318893

\section{Holding Institution}

Smithsonian Libraries

\section{Sponsored by}

Biodiversity Heritage Library

\section{Copyright \& Reuse}

Copyright Status: Not in copyright. The BHL knows of no copyright restrictions on this item.

This document was created from content at the Biodiversity Heritage Library, the world's largest open access digital library for biodiversity literature and archives. Visit BHL at https://www.biodiversitylibrary.org. 